\title{
Thickened tailings loop test to corroborate the hydraulic Hanks model and Buckingham equation
}

\author{
L Vilela BRASS Do Brasil Projetos e Consultoria Tecnica LTDA, Brazil \\ D Pinto BRASS Do Brasil Projetos e Consultoria Tecnica LTDA, Brazil \\ G Ramos BRASS Do Brasil Projetos e Consultoria Tecnica LTDA, Brazil
}

\begin{abstract}
The disposal of diluted tailings in dams, due to their muddy state, becomes inherently difficult to contain and this poses a high risk to society, as observed in the last two accidents that occurred in Brazil in 2015 and 2019. Therefore, the disposal of coarser tailings becomes more relevant because besides contributing to the reduction of water consumption and environmental impact, it will also require a smaller disposal area. However, to transport a thicker slurry, the viscosity and the yield stress of the tailings will increase. Therefore, for long distance conveying systems, high friction losses are generated in the pipeline. In view of the high operating pressures and the low experience with these pumping systems, it is important to consolidate the hydraulic model used in the design. The loop test setup in this case was used to support the selected hydraulic model. Based on data from a loop test set up at a Brazilian mining company located in the Iron Quadrangle (Quadrilátero Ferrifero), the study proposes to validate the Hanks \& Dadia (1971) model using yield stress correction according to the Buckingham equation presented by Abulnaga (2002). In the loop test, the fine iron ore tailings were pumped using positive displacement pumps. The viscosity of the tailings varied between 0.013 and 0.017 Pa.s and the yield stress between 31 and $42 \mathrm{~Pa}$. Very close results were observed between the actual data from the loop test and the head loss calculation by the Hanks \& Dadia (1971) model using the yield stress correction, according to the Buckingham equation.
\end{abstract}

Keywords: Hanks model, loop test, thicker slurry, tailings, rheology

\section{Introduction}

The directional plan for tailings disposal in the mining industry in Brazil is undergoing accelerated changes, especially after the accidents in 2015 at Fundão Dam, the largest environmental accident in Brazil, and in 2019 at B1 Córrego do Feijão Dam, the largest work-related accident in Brazil.

From these events, mining companies have been working hard to reduce the use of dams or in many cases, eliminate them.

The alternatives considered in the disposal of the tailings are the following:

1. Conventional tailings disposal in reservoirs with greater geotechnical stability, e.g. exhausted mine pits.

2. Segregation of tailings, filtering, stacking of coarse tailings and hydraulic disposal for fine tailings.

3. Filtration and stacking of total tailings (coarse and fine).

4. Filtration and stacking of total tailings with overburden mining.

5. Disposal in the form of thick tailings.

The choice among the alternatives described was made according to the availability of the area, technical and financial studies, ore characteristics and the dams' safety level, among others. 
The project described in this study consists of disposing the thickened tailings in an exhausted pit. This concept of design has the following main advantages: optimisation of the capacity of the tailings reservoirs, reduction of the tailings containment structures, smaller environmental impact area and smaller process water consumption and transportation. Figure 1 shows the comparison between thickened tailings reservoir and conventional tailings reservoir.

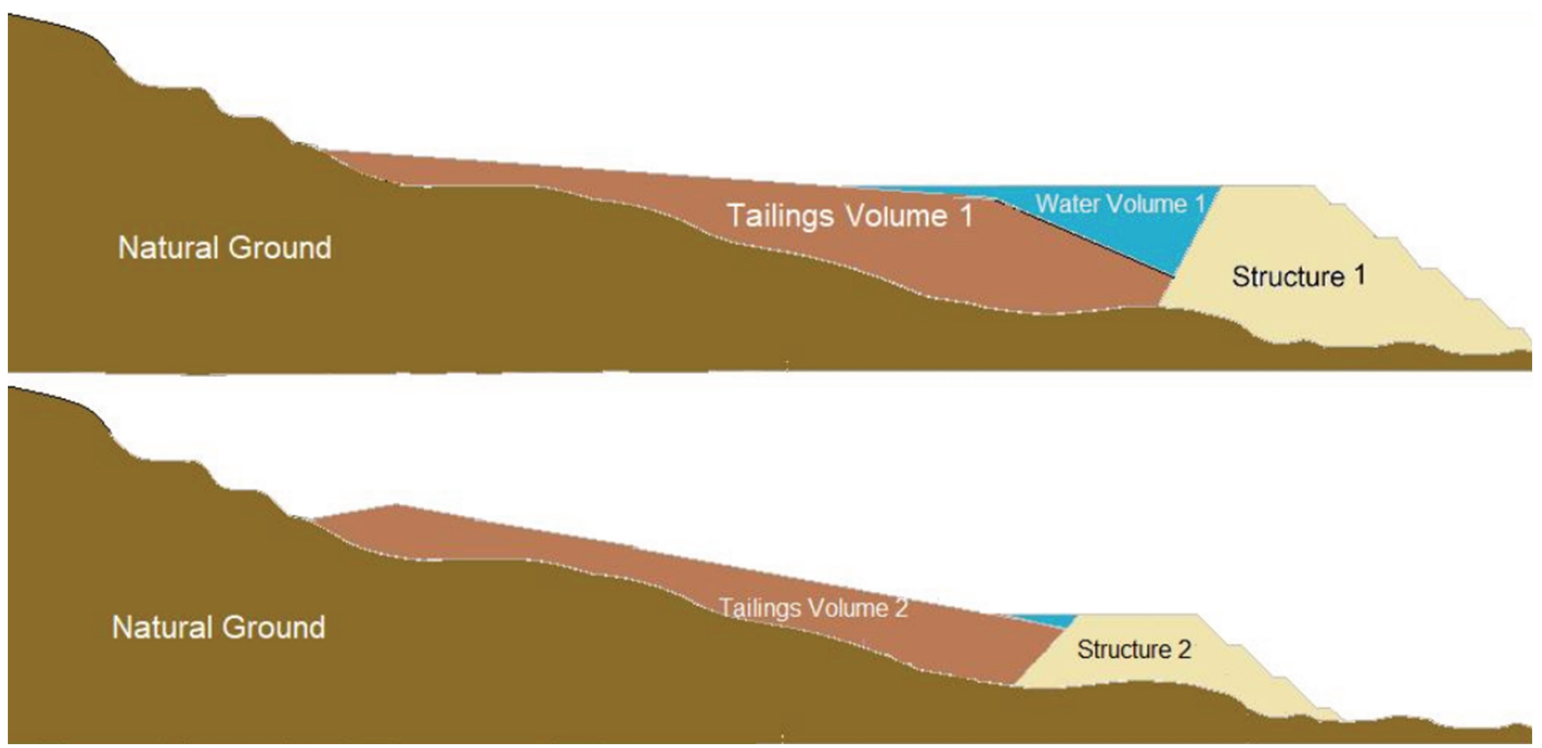

\section{Figure 1 Comparison between conventional tailings reservoir (1) and thickened tailings reservoir (2)}

For most conventional systems, slurry transport occurs in turbulent flow condition, as it is technically easier to handle. However, tailings with a high content of solids and fine particles have high transition velocities from laminar to turbulent regimes. Therefore, for homogeneous mixtures, the laminar regime becomes an attractive possibility from a technical and economic point of view (Abulnaga 2002).

Figure 2 shows the comparison of two typical velocity curves that are commonly used in determining the minimum transport velocity of a heterogenous or pseudo-homogeneous slurry. Deposition velocity is the flow velocity below which particles will settle to the bottom of the pipe, while transition velocity is the velocity above which turbulent flow occurs. Turbulent flow ensures the suspension of solids while in transit. For conventional tailings, both deposition and transition velocities are calculated, and the minimum velocity is determined by whichever of the two is greater.

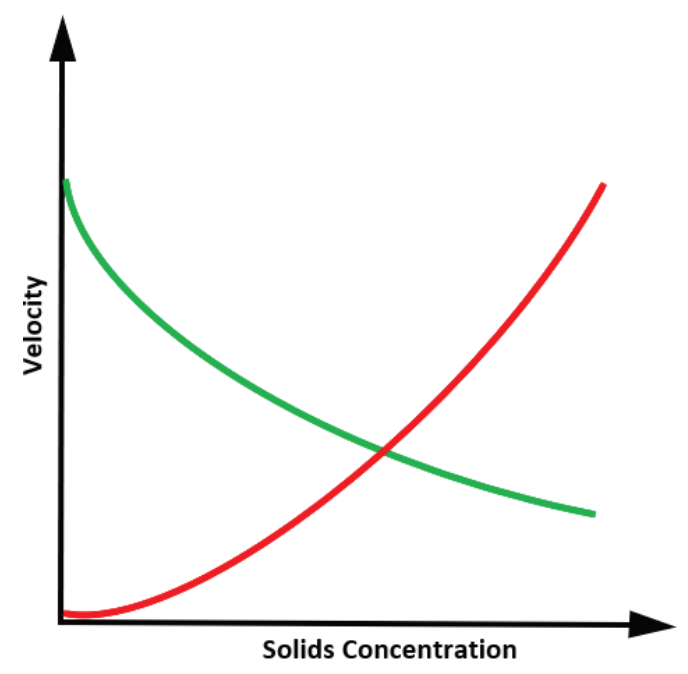

Transition Velocity

Deposition Velocity

Figure 2 Conventional tailings: transition velocity $\times$ deposition velocity 
Thickened tailings, on the other hand, are of higher solids concentration and in this study, contain large amounts of fine particles. The mixture is often described as homogeneous where the solids do not separate easily and remain suspended for a period of time. Homogeneous slurry generally has high viscosity and yield stress. Thus, due to the almost complete absence of settling particles, it is possible to design a pumping system that would transport the solids under the laminar regime. The experiments of Gillies et al. (1999) showed that a pressure gradient in the order of $2 \mathrm{kPa} / \mathrm{m}$ is required to convey significant amounts of sand $(0.43 \mathrm{~mm})$ in laminar flow. Cooke (2002) found the same pressure gradient as Gillies et al. (1999), the tests were performed with clay slurry and sand particles (between $0.045 \mathrm{~mm}$ and $0.212 \mathrm{~mm}$ ).

The thickened tailings disposal system discussed in this paper was designed according to the Hanks \& Dadia (1971).

\section{$2 \quad$ Loop test}

The loop test plant was installed at a Brazilian mining company located in the Iron Quadrangle (Quadrilátero Ferrífero). Figure 3 shows the actual installation.

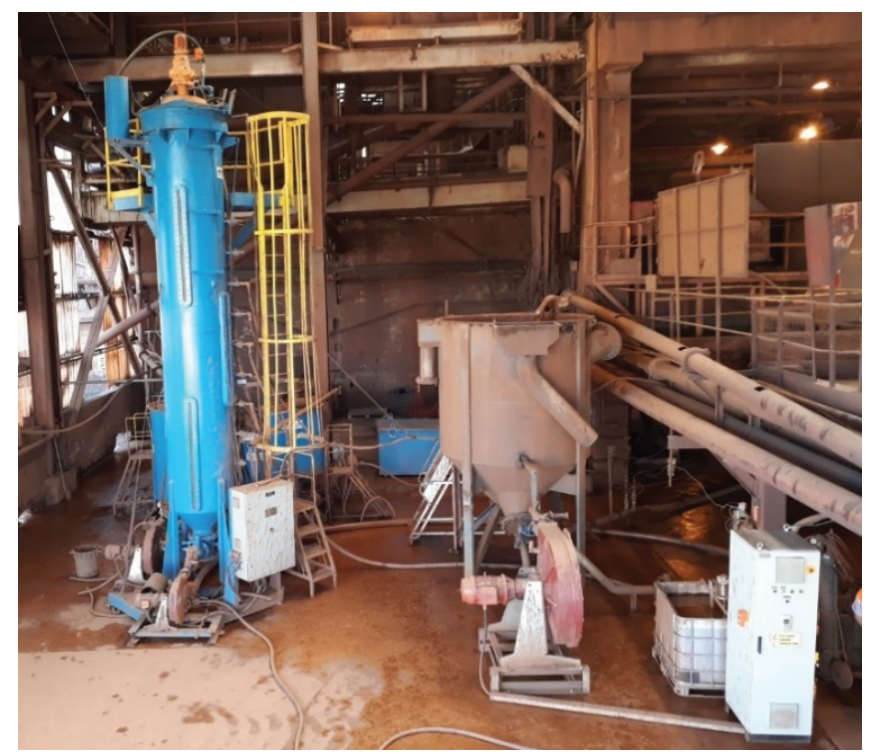

\section{Figure 3 Loop test plant}

System components are described below as follows:

1. High density thickener.

2. Tank: volume $9.6 \mathrm{~m}^{3}$ (2,250 $\mathrm{mm}$ of diameter and $4,100 \mathrm{~mm}$ of height).

3. Pump: power $16 \mathrm{~kW}$ with variable frequency drive.

4. Pipe: pipe of PEAD with $93.8 \mathrm{~mm}$ of inner diameter and project pressure of $10 \mathrm{kgf} / \mathrm{cm}^{2}$. The length of tube is $58.25 \mathrm{~m}$.

5. Instruments:
a. Flowmeter.
b. Densimeter.
c. Pressure meter at the pump discharge.
d. Temperature meter.
e. Pressure differential meter at the loop.
f. Pressure meter at the end of the loop. 
Figure 4 indicates a pipe and instrumentation diagram of the loop test plant.
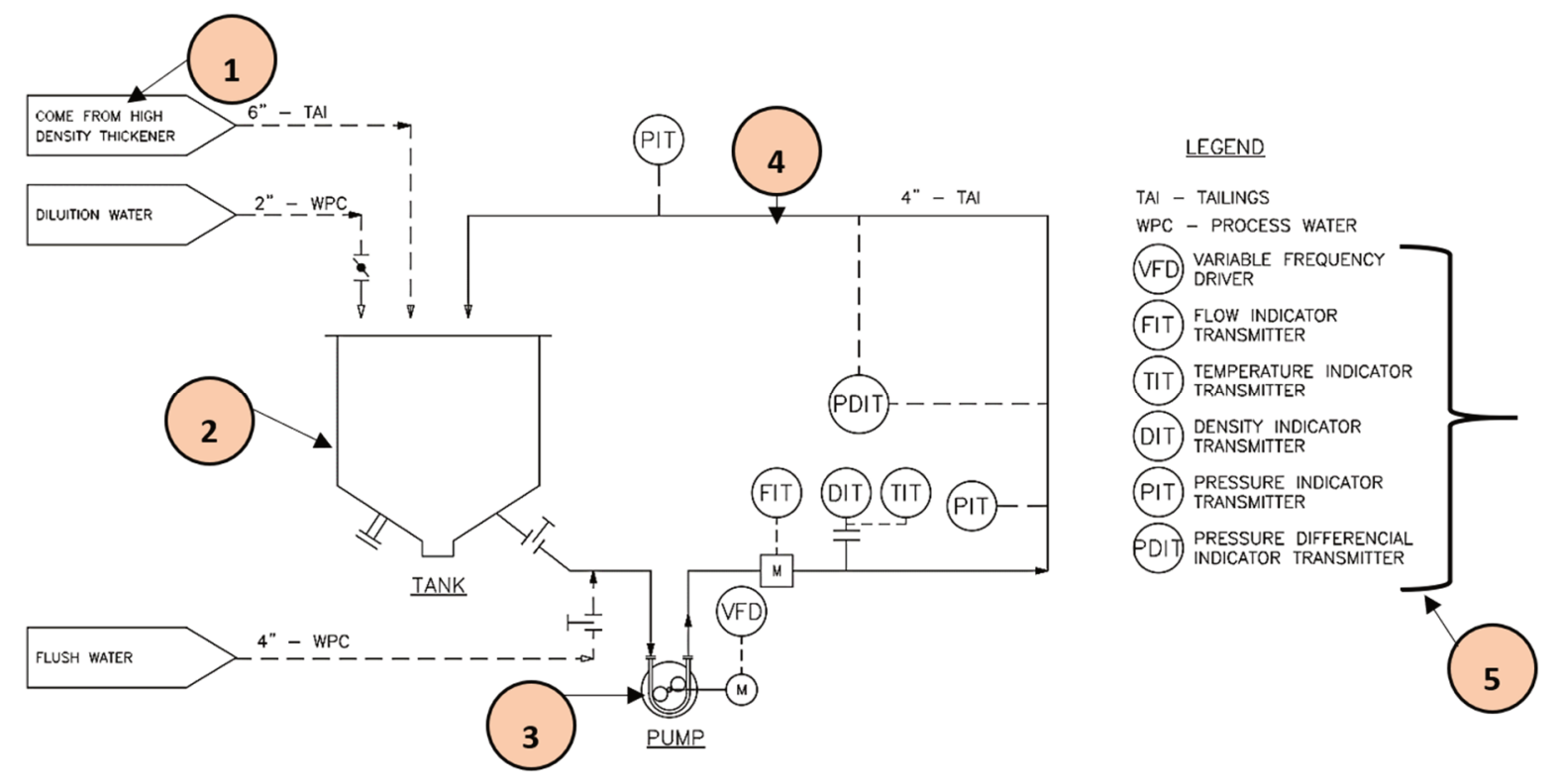

Figure 4 Pipe and instrumentation diagram: loop test plant

\subsection{Methodology}

\subsubsection{Test loop}

The testing methodology in the loop test had four main steps.

Step 1: Water was pumped through the loop test to calibrate the system. In this step, the following measurements and checks were made:

- Water temperature measurement.

- Identification of local head loss in the system.

Step 2: Slurry was pumped through the loop test with three different solids concentrations to determine the real head loss:

- Concentration 1: 52.45\%.

- Concentration 4: 53.29\%.

- Concentration 5: 54.69\%.

Step 3: A rheological test was carried out on each slurry batch pumped by the loop test and its concentration of solids was determined. The rheological test was executed using a rotational concentric cylinder rheometer. In steps 1 and 2, the following data was recorded:

- Flow rate.

- Temperature.

- Density.

- Pump discharge pressure.

- Pressure at the end of the loop.

- Differential pressure between the beginning and the end of the loop.

- Motor speed. 


\subsubsection{Theorical head losses}

Actual head loss was compared with the calculated head loss. The Darcy-Weisbach equation was used to calculate the theorical water head loss, while the Hanks \& Dadia (1971) model was used to calculate the theorical thickened slurry head loss.

Head loss of piping components were correlated to a pipe length using Netto et al. (1998) and this length was converted to HDPE length due to the difference in diameter. This conversion was made using the simplified Hazem-Williams's Equation 1.

$$
L e=L\left(\frac{D e}{D}\right)^{4.87}
$$

where:

$$
\begin{aligned}
& \mathrm{Le} \quad=\text { equivalent length. } \\
& \mathrm{L} \quad=\text { know length. } \\
& \mathrm{De} \quad=\text { diameter of equivalent length. } \\
& \mathrm{D} \quad=\text { diameter of know length. }
\end{aligned}
$$

The laminar model developed by Hanks \& Dadia (1971) uses the viscosity and the yield stress to determine the head loss. The yield stress used in the Hanks model (TO) was corrected, according to the Buckingham equation (Equation 2).

$$
\frac{8 V}{D I}=\frac{\tau_{w}}{\eta}\left[1-\frac{4}{3}\left(\frac{\tau_{0}}{\tau_{w}}\right)+\frac{1}{3} \frac{\tau_{0}^{4}}{\tau_{w}^{4}}\right]
$$

where:

$$
\begin{aligned}
& \mathrm{V} \quad=\text { fluid velocity. } \\
& \mathrm{DI} \quad=\text { inner diameter. } \\
& \tau_{0} \quad=\text { yield stress for a Bingham plastic or yield pseudoplastic. } \\
& \tau_{\mathrm{w}} \quad=\text { shear stress at the wall. } \\
& \eta \quad=\text { absolute viscosity. }
\end{aligned}
$$

The yield stress corrected by Buckingham equation is used to determine the Hedstrom number (Equation 3 ). The Hedstrom number is used to determine the friction factor using the equation developed by Hanks \& Dadia (1971) (Equations 4 and 5) and modified by Darby \& Melson (1981) and Darby et al. (1992) (Equations 6 and 7). The friction factor, $f_{D}$ (Equation 9), is used to determine the head loss using Darcy's model, according to Abulnaga (2002). The friction factor, $f_{D}$, depends on the fanning factor, $f_{n}$ (Equation 6 ). To calculate the fanning factor, it is necessary to determinate $f_{L}$ (Equation 8).

$$
\begin{gathered}
\mathrm{He}=\frac{D^{2} \tau_{0} \rho}{\eta^{2}} \\
f_{T}=10^{A} R e^{-0.193} \\
A=-1,47\left(1+0,146 e^{-2.9 \times 0.0001 H e}\right) \\
f_{n}=\left(f_{L}^{m}+f_{T}^{m}\right)^{\left(\frac{1}{m}\right)} \\
\mathrm{m}=1.7 \frac{40,000}{\operatorname{Re}} \\
f_{L}=\frac{16}{\operatorname{Re}}\left(1+\frac{\operatorname{Re}}{6 \mathrm{He}}-\frac{R e^{4}}{3 f_{L}^{3} H e^{7}}\right) \\
f_{D}=4 f_{n}
\end{gathered}
$$


where:

$$
\begin{aligned}
& \mathrm{He} \quad=\text { Hedstrom number. } \\
& \operatorname{Re}=\text { Reynolds number. } \\
& D \quad=\text { inner diameter. } \\
& \rho \quad=\text { fluid density. } \\
& \tau_{0} \quad=\text { yield stress corrected by Buckingham equation. } \\
& \eta \quad=\text { absolute viscosity. } \\
& f_{T} \quad=\text { friction factor for turbulent regime. } \\
& f_{L} \quad=\text { friction factor for laminar regime. } \\
& f_{D} \quad=\text { Darcy friction factor. } \\
& f_{n} \quad=\text { Fanning friction factor. } \\
& m \quad=\text { exponent of Fanning friction factor equation. } \\
& A \quad=\text { exponent of friction factor for turbulent regime. }
\end{aligned}
$$

\section{$2.2 \quad$ Results}

\subsubsection{System calibration with water}

The water temperature was measured, and the water viscosity was defined for this temperature to perform the system calibration. The calibration is important to verify the measuring instruments and local head losses that were not considered.

Table 1 presents the water data.

\section{Table 1 Water data}

\begin{tabular}{lll}
\hline Temperature $\left({ }^{\circ} \mathrm{C}\right)$ & Density $\left(\mathrm{kg} / \mathrm{m}^{3}\right)$ & Viscosity $(\mathrm{Pa} . \mathrm{s})$ \\
\hline 23 & 997.8 & 0.00093 \\
\hline
\end{tabular}

The local head losses identified in the loop and the equivalent lengths are shown in Table 2, according to Netto et al. (1998).

Table 2 Localised head losses

\begin{tabular}{ll}
\hline Elements of local head losses & Equivalent length $(\mathrm{m})$ \\
\hline 2 (T) of PIT & 1.6 \\
Interface steel/HDPE & 1.1 \\
Interface HDPE/steel & 2.2 \\
$0.5 \mathrm{~m}$ of steel pipe (73.5 mm inner diameter) & 0.5 \\
\hline
\end{tabular}

The total local head losses in length form are $22.96 \mathrm{~m}$ according to calculation shown in methodology. The total pipe length with the local head losses is $81.21 \mathrm{~m}$.

The data collected during the test loop with water are shown in Table 3. The measured and calculated data had an average difference of $10 \%$ and it can be explained by the instrument's measurement uncertainty. 
Table 3 Data of loop test with water

\begin{tabular}{lllllllll}
\hline $\begin{array}{l}\text { Flow rate } \\
\left(\mathbf{m}^{3} / \mathrm{h}\right)\end{array}$ & $\begin{array}{l}\Delta p \\
\text { measure } \\
\mathbf{d}(\mathrm{kPa})\end{array}$ & $\begin{array}{l}\text { Motor } \\
\text { speed } \\
(\mathbf{r p m})\end{array}$ & $\begin{array}{l}\text { Pump } \\
\text { speed } \\
(\mathbf{r p m})\end{array}$ & $\begin{array}{l}\text { Velocity } \\
(\mathbf{m} / \mathbf{s})\end{array}$ & $\begin{array}{l}\Delta p \\
\text { measured } \\
(\mathbf{k P a} / \mathbf{k m})\end{array}$ & $\begin{array}{l}\Delta p \\
\text { calculated } \\
(\mathbf{k P a} / \mathbf{k m})\end{array}$ & $\begin{array}{l}\text { Temp. } \\
\left({ }^{\circ} \mathrm{C}\right)\end{array}$ & $\begin{array}{l}\boldsymbol{\rho} \\
\left(\mathrm{g} / \mathrm{cm}^{3}\right)\end{array}$ \\
\hline 19.30 & 7.06 & 800.0 & 16.13 & 0.78 & 84.41 & 64.71 & 23.0 & 1.0 \\
21.30 & 7.72 & 810.0 & 16.33 & 0.86 & 92.24 & 77.33 & 23.0 & 1.0 \\
24.50 & 9.07 & 900.5 & 18.16 & 0.98 & 108.44 & 98.22 & 23.0 & 1.0 \\
26.75 & 10.63 & $1,099.5$ & 22.17 & 1.08 & 127.03 & 117.40 & 23.0 & 1.0 \\
30.15 & 13.52 & $1,210.0$ & 24.40 & 1.21 & 161.59 & 144.72 & 23.0 & 1.0 \\
38.45 & 20.50 & $1,508.5$ & 30.41 & 1.55 & 245.04 & 228.82 & 23.0 & 1.0 \\
40.30 & 22.11 & $1,596.0$ & 32.18 & 1.62 & 264.35 & 248.38 & 23.0 & 1.0 \\
44.19 & 24.76 & $1,713.5$ & 34.55 & 1.78 & 295.98 & 295.96 & 23.0 & 1.0 \\
46.65 & 27.67 & $1,846.0$ & 37.22 & 1.88 & 330.83 & 327.71 & 23.0 & 1.0 \\
\hline
\end{tabular}

Figure 5 presents the comparison between the measured head loss data with water and the calculated values.

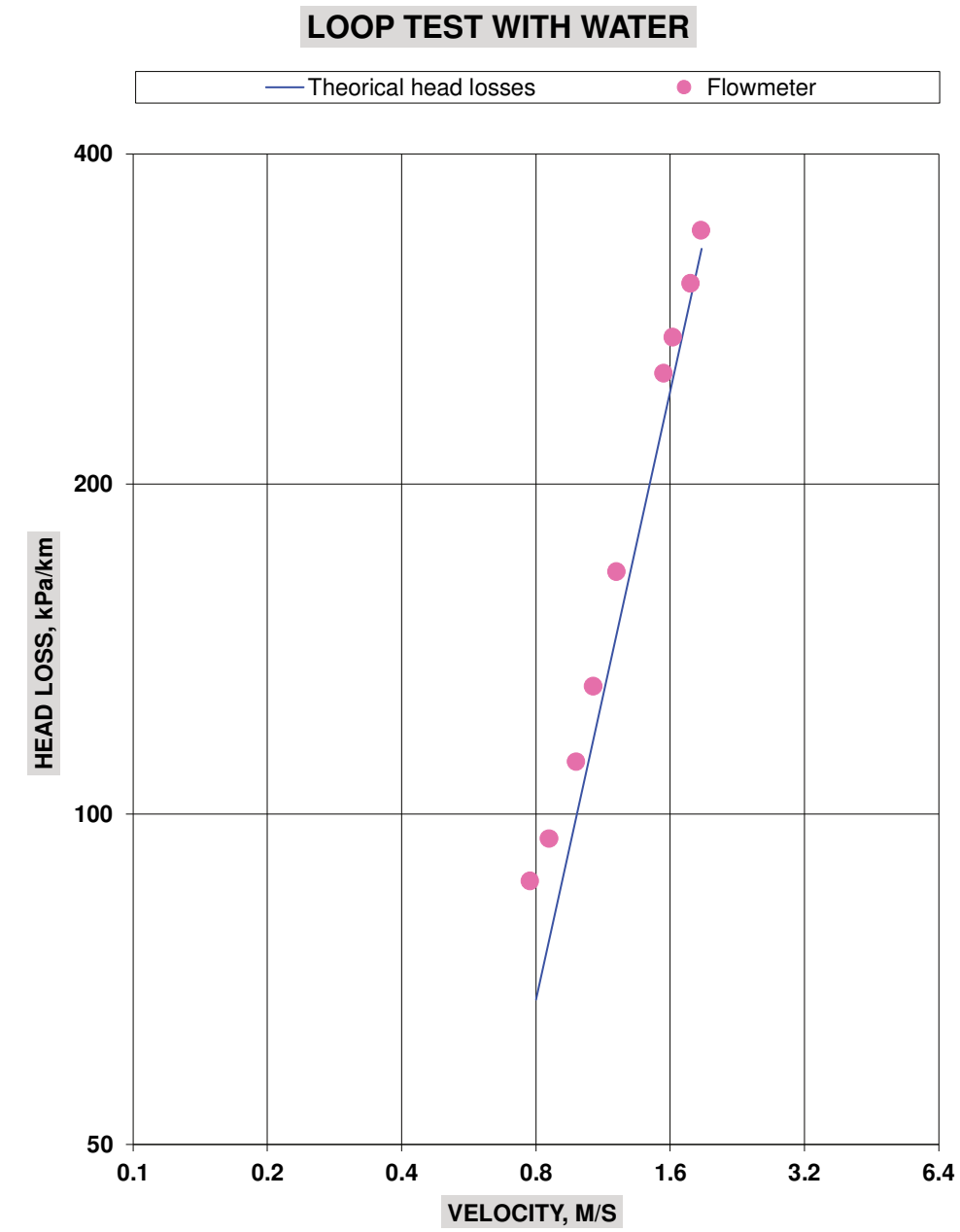

Figure 5 Comparison between real head loss and calculated head loss for water 


\subsubsection{The rheological tests}

The viscosity and wall yield stress were defined according to Figure 6 and the values are presented in Table 4 . Figure 6 shows that the wall yield stress (tw) determined for rheological testing and the Bingham model is higher than the fluid yield stress ( $(\tau 0)$. Thus, the Buckingham equation (Equation 2 ) is a way to make this correction.

The shear rate versus shear stress curves from the rheological tests are shown in Figure 7 . The curves were interpreted using Bingham's model. The Bingham fluid viscosity was a linear function of shear rate, so the viscosity was interpreted in the linear part of the curves. The analysis performed using Bingham's model provided the wall yield stress $\left(\tau_{w}\right)$. The fluid yield stress $\left(\tau_{0}\right)$ was defined by the Buckingham equation (Equation 2), according to Abulnaga (2002).

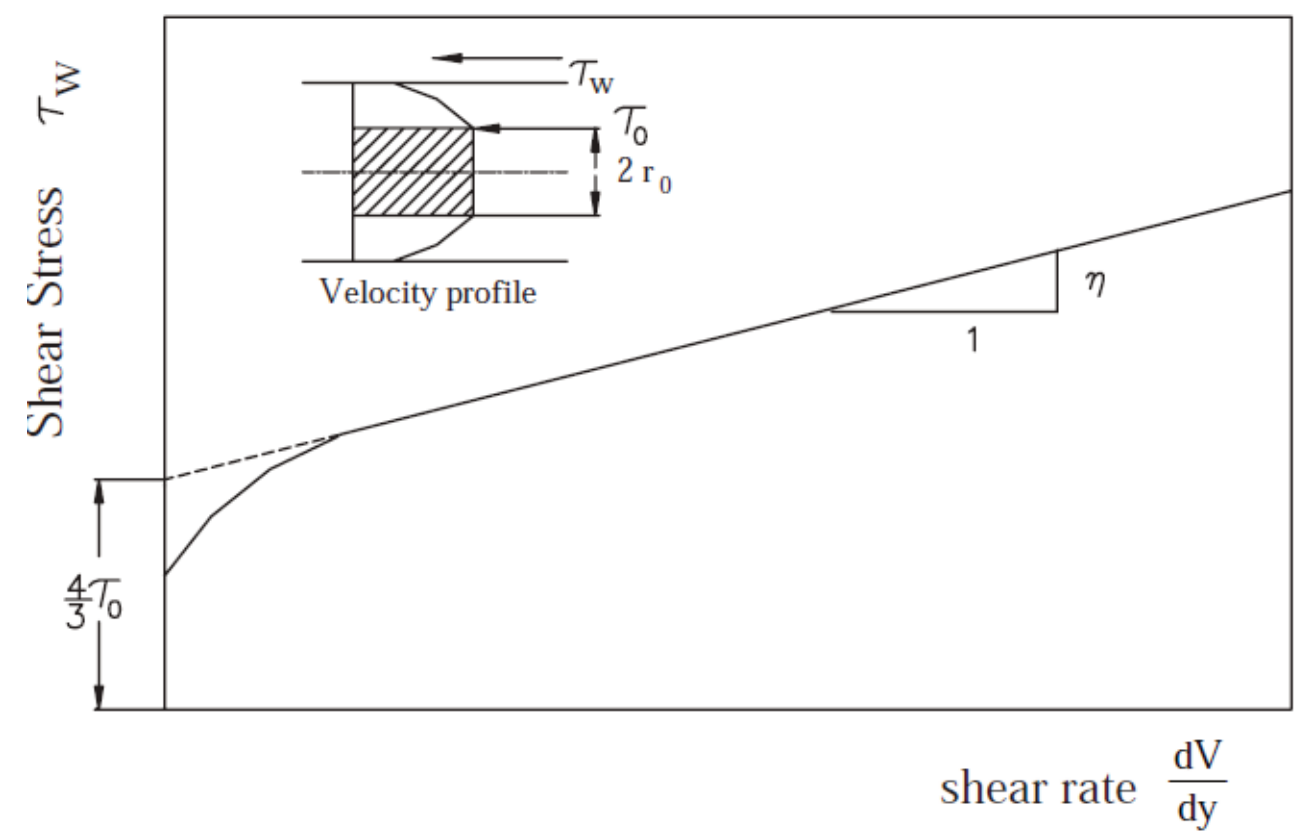

Figure 6 Shear rate $\times$ shear stress by Bingham plastic (Abulnaga 2002)

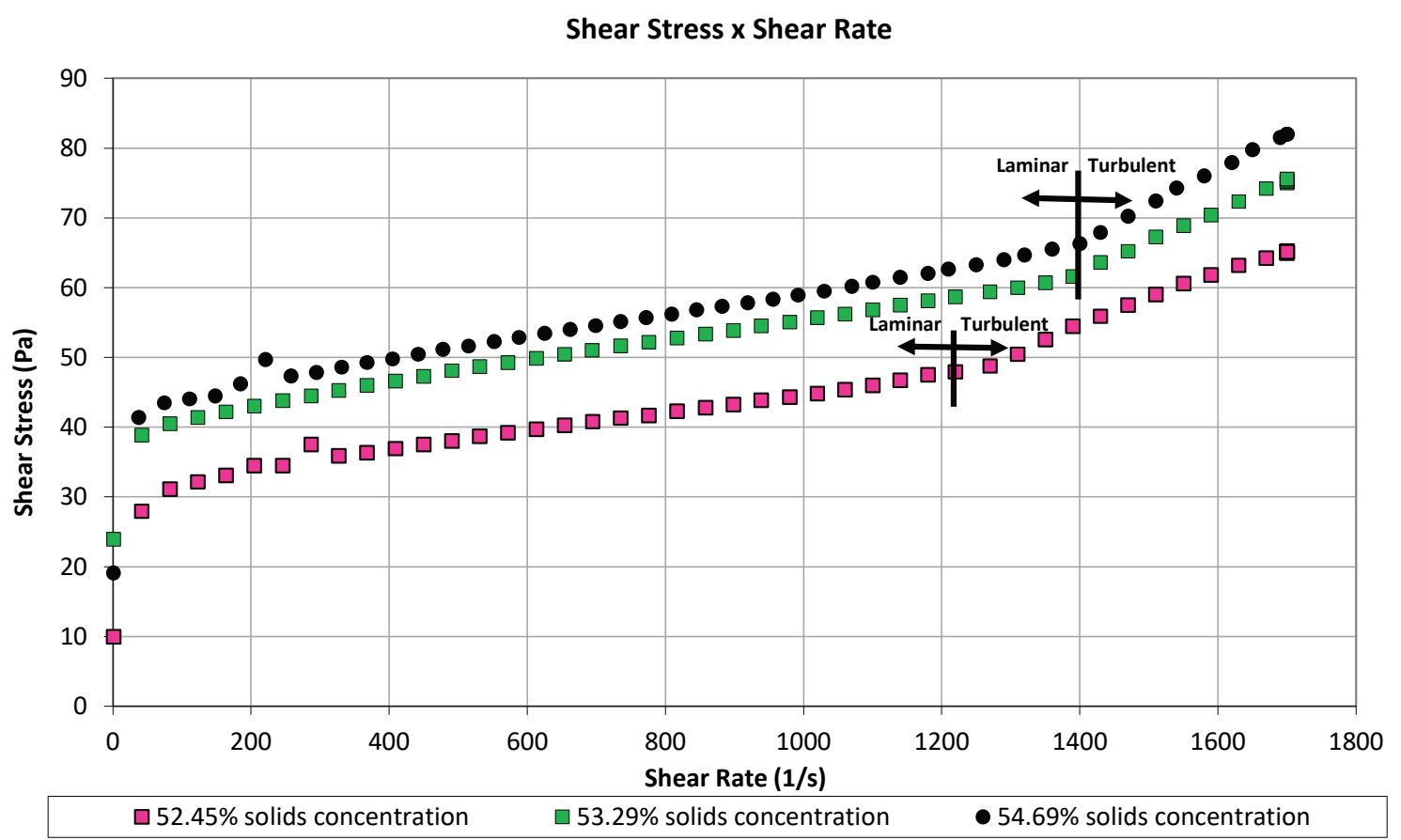

Figure 7 Flow curve: shear stress $\times$ shear rate 
Table 4 Rheological test data

\begin{tabular}{lll}
\hline $\begin{array}{l}\text { Solids concentration } \\
\text { by mass (\%) }\end{array}$ & $\begin{array}{l}\text { Absolute viscosity } \\
(\text { Pa.s) }\end{array}$ & $\begin{array}{l}\text { Yield stress } \\
\left(\boldsymbol{\tau}_{\mathrm{w}}, \mathrm{Pa}\right)\end{array}$ \\
\hline 52.45 & 0.0130 & 31.7 \\
53.29 & 0.0143 & 41.1 \\
54.69 & 0.0167 & 42.4 \\
\hline
\end{tabular}

\subsubsection{Head losses with thickened tailings in loop test}

The data collected during the loop test with thickened tailings are shown in Tables 5, 6, and 7. The tables also present the corrected yield stress, using the Buckingham equation.

Table 5 Data of loop test with slurry: $\mathbf{5 2 . 4 5 \%}$ solids concentration

\begin{tabular}{lllllllll}
\hline $\begin{array}{l}\text { Flow rate } \\
\left(\mathbf{m}^{\mathbf{3}} / \mathrm{h}\right)\end{array}$ & $\begin{array}{l}\Delta p \\
\text { measured } \\
(\mathbf{k P a})\end{array}$ & $\begin{array}{l}\text { Motor } \\
\text { speed } \\
(\mathbf{r p m})\end{array}$ & $\begin{array}{l}\text { Pump } \\
\text { speed } \\
(\mathbf{r p m})\end{array}$ & $\begin{array}{l}\text { Velocity } \\
(\mathbf{m} / \mathbf{s})\end{array}$ & $\begin{array}{l}\Delta p \\
\text { measured } \\
(\mathbf{k P a} / \mathbf{k m})\end{array}$ & $\begin{array}{l}\Delta p \\
\text { calculated } \\
(\mathbf{k P a} / \mathbf{k m})\end{array}$ & $\rho\left(\mathrm{g} / \mathrm{cm}^{\mathbf{3}}\right)$ & $\mathrm{T}_{0}(\mathrm{~Pa})$ \\
\hline 19.85 & 92.42 & 800.5 & 16.14 & 0.80 & $1,138.09$ & $1,250.75$ & 1.64 & 25.64 \\
24.50 & 100.78 & 951.5 & 19.18 & 0.98 & $1,241.03$ & $1,231.35$ & 1.64 & 24.69 \\
27.70 & 101.29 & $1,100.0$ & 22.18 & 1.11 & $1,247.31$ & $1,214.61$ & 1.64 & 24.06 \\
32.75 & 104.13 & $1,249.0$ & 25.18 & 1.32 & $1,282.29$ & $1,204.61$ & 1.64 & 23.42 \\
\hline
\end{tabular}

Table 6 Data of loop test with slurry: $53.29 \%$ solids concentration

\begin{tabular}{lllllllll}
\hline $\begin{array}{l}\text { Flow } \\
\text { rate } \\
\left(\mathbf{m}^{3} / \mathbf{h}\right)\end{array}$ & $\begin{array}{l}\Delta \mathbf{p} \\
\text { measured } \\
(\mathbf{k P a})\end{array}$ & $\begin{array}{l}\text { Motor } \\
\text { speed } \\
(\mathbf{r p m})\end{array}$ & $\begin{array}{l}\text { Pump } \\
\mathbf{s p e e d} \\
(\mathbf{r p m})\end{array}$ & $\begin{array}{l}\text { Velocity } \\
(\mathbf{m} / \mathbf{s})\end{array}$ & $\begin{array}{l}\Delta \mathbf{p} \\
\text { measured } \\
(\mathbf{k P a} / \mathbf{k m})\end{array}$ & $\begin{array}{l}\Delta \mathbf{p} \\
\text { calculated } \\
(\mathbf{k P a} / \mathbf{k m})\end{array}$ & $\begin{array}{l}\mathbf{\rho} \\
\left(\mathbf{g} / \mathrm{cm}^{3}\right)\end{array}$ & $\begin{array}{l}\mathbf{T}_{0} \\
(\mathbf{P a})\end{array}$ \\
\hline 19.75 & 114.10 & 798.5 & 16.10 & 0.79 & $1,405.06$ & $1,604.48$ & 1.65 & 33.26 \\
24.70 & 124.13 & 956.0 & 19.27 & 0.99 & $1,528.57$ & $1,575.75$ & 1.65 & 32.03 \\
27.80 & 123.08 & $1,095.0$ & 22.08 & 1.12 & $1,515.64$ & $1,554.99$ & 1.65 & 31.21 \\
32.33 & 128.09 & $1,250.0$ & 25.20 & 1.30 & $1,577.34$ & $1,536.56$ & 1.65 & 30.39 \\
\hline
\end{tabular}

Table 7 Data of loop test with slurry: $54.69 \%$ solids concentration

\begin{tabular}{lllllllll}
\hline $\begin{array}{l}\text { Flow rate } \\
\left(\mathbf{m}^{\mathbf{3}} / \mathbf{h}\right)\end{array}$ & $\begin{array}{l}\boldsymbol{\Delta} \mathbf{p} \\
\text { measured } \\
(\mathbf{k P a})\end{array}$ & $\begin{array}{l}\text { Motor } \\
\text { speed } \\
(\mathbf{r p m})\end{array}$ & $\begin{array}{l}\text { Pump } \\
\text { speed } \\
(\mathbf{r p m})\end{array}$ & $\begin{array}{l}\text { Velocity } \\
(\mathbf{m} / \mathbf{s})\end{array}$ & $\begin{array}{l}\Delta \mathbf{p} \\
\text { measured } \\
(\mathbf{k P a} / \mathbf{k m})\end{array}$ & $\begin{array}{l}\Delta \mathbf{p} \\
\text { calculated } \\
(\mathbf{k P a} / \mathbf{k m})\end{array}$ & $\begin{array}{l}\mathbf{p} \\
\left(\mathbf{g} / \mathbf{c m}^{3}\right)\end{array}$ & $\begin{array}{l}\mathbf{T}_{0} \\
(\mathbf{P a})\end{array}$ \\
\hline 20.40 & 120.54 & 800.0 & 16.13 & 0.82 & $1,484.36$ & $1,656.37$ & 1.65 & 33.90 \\
22.25 & 191.79 & 909.5 & 18.34 & 0.89 & $2,361.76$ & $1,647.60$ & 1.65 & 33.48 \\
25.80 & 129.96 & $1,009.5$ & 20.35 & 1.04 & $1,600.36$ & $1,628.01$ & 1.65 & 32.63 \\
27.58 & 130.92 & $1,104.5$ & 22.27 & 1.11 & $1,612.19$ & $1,619.53$ & 1.65 & 32.20 \\
\hline
\end{tabular}

Figure 8 shows the comparison between the measured head loss data with the thickened tailings and the calculated values. The measured and calculated data had an average difference of $7 \%$ for the slurry concentration of $52.45 \%, 53.29 \%$, and $54.69 \%$. The difference indicates that a minimum design factor of $7 \%$ should be used using Hanks \& Dadia's (1971) model and Buckingham's equation (Equation 2) for the head 
loss calculation. The differences between the actual and calculated data can be explained by the accuracy of the instruments, the calculated values for local head losses and the equivalent length.

The lines show, as the velocity increases, the head loss decreases, because as the velocity increases, $\tau 0$ decreases using Buckingham's equation. Reducing $\tau 0$ causes a reduction in head loss. But the actual data showed an opposite relation between velocity and the head loss from the calculated data. This opposite relation can be explained by the approach of the transition region with increasing velocity.

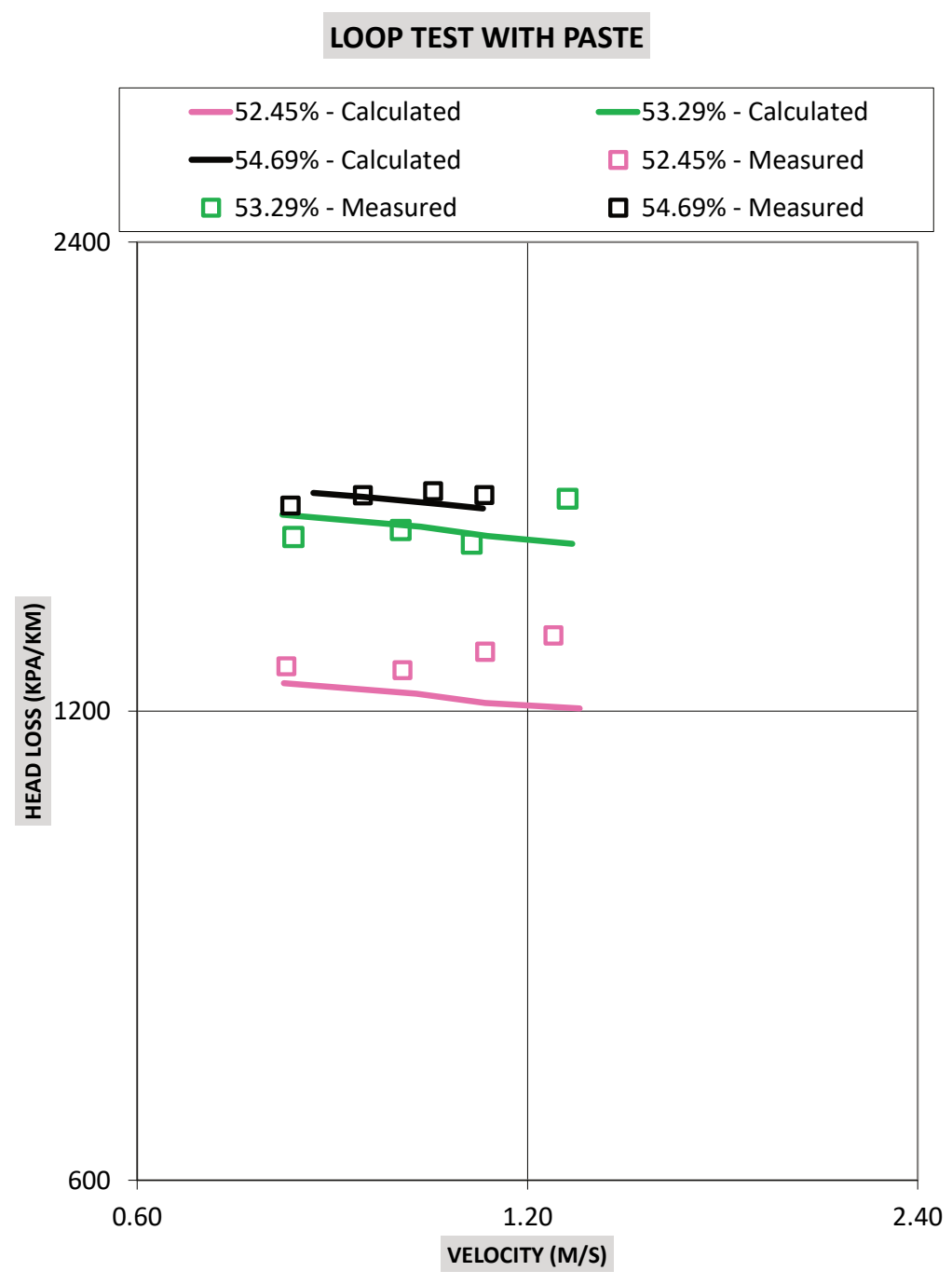

Figure 8 Head loss curves: comparison between real and calculated head losses for thickened tailings

\section{Conclusion}

Very close results were observed between the real data of the loop test and the head loss calculation by the Hanks \& Dadia (1971) model using the yield stress correction, according to the Buckingham equation.

For the flow velocity range between 1.0 and $1.3 \mathrm{~m} / \mathrm{s}$, the viscosity range between 0.013 and $0.017 \mathrm{~Pa} . \mathrm{s}$ and the wall yield stress range between 31.7 and $42.4 \mathrm{~Pa}$, the TO/Tw ratio found from Buckingham equation was 0.8 for all the solids concentration.

The measured and calculated data had an average difference of $7 \%$ for the slurry concentration $52.45 \%$, $53.29 \%$ and $54.69 \%$. The difference indicates that a minimum design factor of $7 \%$ using the model of Hanks \& Dadia (1971) and Buckingham equation (Equation 2) should be used for the head loss calculation, but it is necessary to compare this data with other systems to confirm this design factor. 


\section{References}

Abulnaga, B 2002, Slurry Systems Handbook, McGraw-Hill International Book Company, New York.

Cooke, R 2002, 'Laminar flow settling: the potential for unexpected problems', Proceedings of the 15th International Conference on the Hydraulic Transport of Solids: Hydrotransport 15, BHR Group, Cranfield, pp. 121-133.

Darby, R \& Melson, J 1981, 'How to predict the friction factor flow of Bingham plastics', Chemical Engineering, vol. 88, no. 26, pp. 59-61.

Darby, R, Mun, R \& Boger, DV 1992, 'Prediction friction loss in slurry pipes', Chemical Engineering, vol. 99 no. 9, pp. $116-119$.

Gillies, RG, Hill, KB, McKibben, MJ \& Shook, CA 1999, 'Solids transport by laminar Newtonian flows', Journal of Powder Technology, vol. 104, pp. 269-277.

Hanks, RW \& Dadia, BH 1971, 'Theoretical analysis of the turbulent flow of non-Newtonian slurries in pipes', American Journal of Chemical Engineering, vol. 7, no. SPE-1682-PA, pp. 554-557.

Netto, A, Fernandez, M, Araujo, R \& Ito, A, 1998, Manual de hidráulica, Edgar Blücher Ltda, São Paulo. 
